\title{
Visualizing Social Facts: Otto Neurath's ISOTYPE Project
}

\author{
Frank Hartmann
}

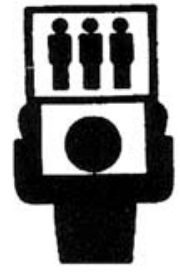

ISOTYPE

Figure 15.1 Logo used by Neurath in the 1920s and 1930s (Neurath 1936)
A pioneer in many respects, Otto Neurath made contributions in the areas of socialist politics, political economy, the theory of science, sociology and social philosophy. Especially innovative, however, were his revolutionary ideas about communication based on the role of media in the making of modern man as a social technology for achieving socialist objectives. Within the context of his Wissenschaftliche Weltauffassung [Scientific Conception of the World - The Vienna Circle] he argued for a new form of encyclopedic integration of knowledge. Insisting on the need for absolute clarity of expression, he developed an innovative form of scientific expression to help achieve this, an 'international picture language'. It was based on a new pictographic design system: ISOTYPE, an acronym for 'International System Of TYpographic Picture Education' (Figure 15.1) (Neurath 1936, 7).

The starting point for the ISOTYPE project was the Gesellschafts- und Wirtschaftsmuseum [Museum for Society and Economy] founded in Vienna in 1924, and it ended with Neurath's death in Oxford in 1945, after fleeing The Hague when the Germans invaded Holland during the Second World War. Vienna during the interwar period can be regarded as a laboratory of modernity, as an ambitious socialist experiment in enhancing housing and general living conditions for the working classes. ISOTYPE was developed to visualize social and economic relations especially for uneducated persons and to facilitate their understanding of complex data. It was developed from the point of view of a specific socialist conception of adult education and sought to enhance scientific arguments by means of an 'education by the eye' (Neurath 1936, 22).

To achieve this, with the help of graphic designer Gerd Arntz, who joined him in 1927, Neurath developed data graphics, the visual display of quantitative information, into pictorial statistics using what he named the 'Viennese method'. This was a new method of visual education, an innovation in design using diagrams and eventually 
animated film. ${ }^{1}$ The objective was to create a 'helping language' consisting of a set of internationally standardized graphic symbols:

In the Far East we see one language for writing, but a great number of languages for talking. We have made one international picture language (as a helping language) into which statements may be put from all the normal languages of the earth. We have given it the name ISOTYPE. A picture language of this sort is frequently very important and of great use ... because pictures, whose details are clear to everybody, are free from the limits of language: they are international. WORDS MAKE DIVISION, PICTURES MAKE CONNECTION ... It is a language which may be put into words in very different ways (Neurath 1936, 17f).

In the 1920s these graphic symbols were yet to be created. With its twofold goal of information and education, the ISOTYPE project reached beyond pure design ambitions. It would serve strangers coming to a foreign country, as well as it would help uneducated workers to access knowledge. In the end it should even 'be of use as a helping language in an international encyclopaedia of common knowledge' (Neurath 1936, 65). A thesaurus of such symbols for scientific use was planned but never realized for the International Encyclopedia of Unified Science by Charles Morris, Rudolf Carnap, Otto Neurath and others, with its first volumes published in 1938-1939.

Obviously Neurath's interest in the unity of science and the relationship of science to society was not merely theoretical. He insisted on the need for practical means that would compel interest in the application of the social sciences for the good of society. His question was: how can scientists, as social engineers, help to optimize the political and economic conditions of their time? The answer was based on a simple premise, that general living conditions [Lebenslagenkataster], such as lodging, nutrition, clothing and working hours, could be improved, he believed, if they could be measured objectively, using measures based on a strictly scientific foundation of empirical observation and logical analysis (see Neurath 1937).

Neurath's project was deeply embedded in the socialist struggle for a new society. He vigorously expressed his ideas on questions of how to represent scientific results and how to transfer knowledge into society. He had a certain nonchalance in dealing with historical and philosophical encumbrances that appeared to weigh heavily on the scholarly generation of his time. In his view they were metaphysical problems that constituted a burden to be rid of science in the form of sociology was engaged to solve the problems of a modern society.

\section{ISOTYPE Productions: The Background}

After World War I, Neurath became secretary general of the Siedlungs- und Kleingartenwesen (the allotment program that was part of the housing experiment of so-called 'Red Vienna', the socialist governed city). He received municipal

1 ISOTYPE animated diagrams were used in films mostly after 1941, by Paul Rotha Productions in Great Britain. 
funding for exhibitions on housing projects and public healthcare. From 1924 until the Austrian civil war in 1934, the Gesellschafts- und Wirtschaftsmuseum set up as a working office in the fifteenth district of Vienna, became the organization where his projects were carried out. At the Vienna town hall and in other places, early ISOTYPE charts were displayed (Figure 15.2). Among the exhibitions in which Neurath and his team participated outside of Austria was the GESOLEI (Gesundheit, Soziale Fürsorge und Leibesübung) at Düsseldorf in 1926, and they also worked with the Hygiene-museum in Dresden in 1930. In addition Neurath set up studios in Moscow, where Russian artists were trained in the pictorial statistics method (19311934), and after 1934 in The Hague, where there was some cooperation with Paul Otlet's Mundaneum Institute. These extremely successful international initiatives were complemented by assignments, mostly in the form of a series of health charts for fighting tuberculosis, from the City of New York Department of Health in the period 1937-1939 and the National Tuberculosis Association in New York in the period 1938-1942. In the United States, Neurath's work was adopted by designer Rudolf Modley, who created the Pictograph Corporation in Chicago in 1930.

In Vienna, Neurath's work was in the tradition of the science museums that were popular at the time. From them he adopted the idea of using for his exhibitions signs and tables, posters and even objects for hands-on experience. To reach a multitude of common people, the multiplication of display material made possible by the use of ISOTYPE icons was crucial. Neurath believed the 'Museum of the Future' should be brought to the people, not the other way around. It was meant to address common
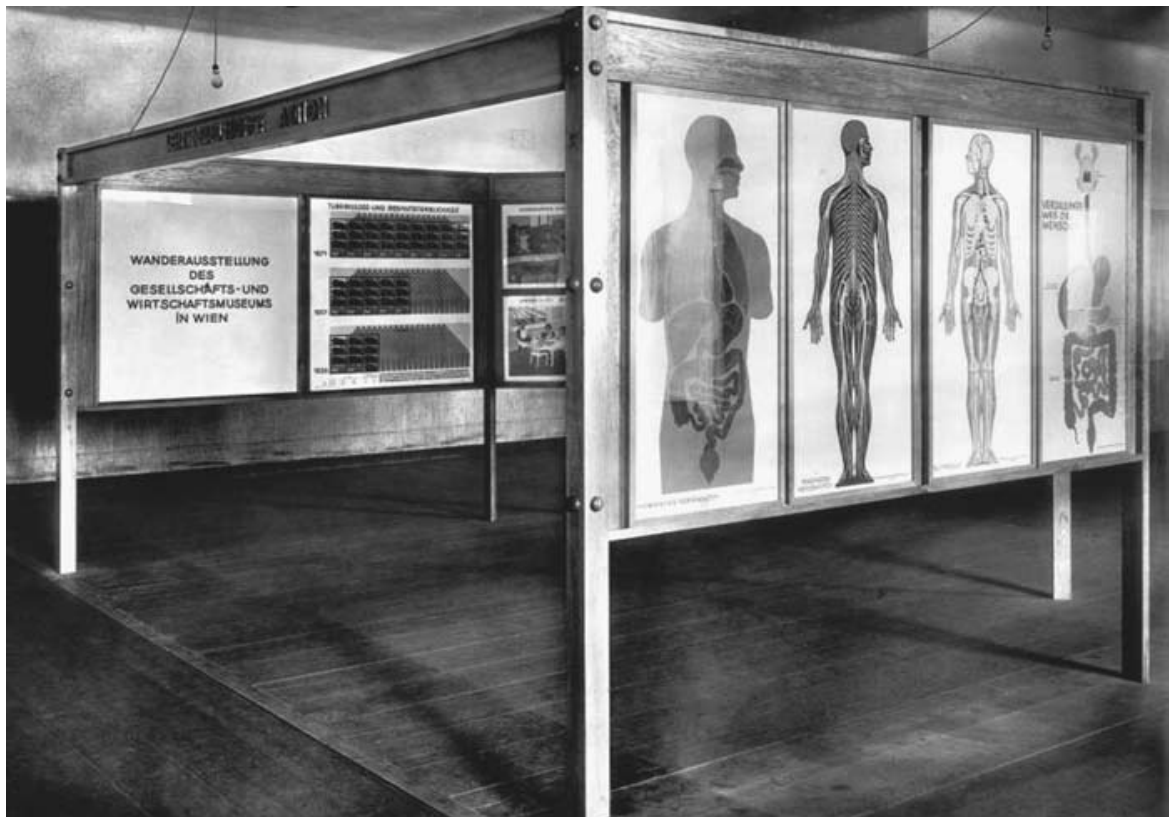

Figure 15.2 Exhibition by the Gesellschafts- und Wirtschaftsmuseum in Vienna, photograph c. 1927 
people, and for its educational purposes he trusted the effect of pictures to be 'greater than the effect of words, especially at the first stage of getting new knowledge' (Neurath 1936, 22). To achieve this, the Gesellschafts- und Wirtschaftsmuseum employed graphic designers Erwin Bernath and Gert Arntz as well as the architect Josef Frank for setting up the exhibitions. Arntz was largely responsible for the master design of the reductionist ISOTYPE images. ${ }^{2}$

\section{Debabelization in Business and Science}

In trying to break through the limitations of alphabetic expression, Neurath was following numerous historical attempts to find or reconstruct an ideal language. The philosopher John Locke, one of many with this interest, claimed at the end of seventeenth century: 'As the main objective of language in communication is to be understood, words are not suitable for this purpose' (Eco 1995, 229). The idea was that a more effective medium, beyond the arbitrary use of words, would enhance iconicity and, as in the case of Leibniz' 'Characteristica Universalis', would lead to the development of an ideal language in which the degree of interpretation would be kept as low as possible. The German logician, Gottlob Frege, later introduced an approach which made use of new forms of scientific expression. He called this 'conceptual writing' (Begriffsschrift, 1879), the main characteristic of which was the optimized use of both dimensions of the writing space (left to right, top to bottom). Frege strongly influenced the 'Vienna Circle' in its struggle for clarity in philosophical forms, which resulted in the groundbreaking work of Rudolf Carnap and Ludwig Wittgenstein. Neurath's approach was a pragmatic one: 'to facilitate the penetration of the scientific world-conception into the forms of personal and public life, in education, upbringing, architecture, and the shaping of economic and social life' (Carnap, Hahn, and Neurath 1929).

The application of ideas to improve the general welfare was what mattered. As an empirical basis for this, Neurath suggested a sociological comparison of living standards to create 'Inventories of Standards of Living' (Neurath 1937), which would show where the need for political action lay. Neurath further suggested two steps in reorganizing scientific communication. At the first level, he believed that communication within the community of investigators should be improved, and at the second level, general access to knowledge should also be improved. The unified language of science, of such interest to the 'Vienna Circle' of which he was part, would be helpful at the first level, and his new pictorial language would be helpful at the second level. Once it was agreed that the epistemic reservoir of modern society was constantly increasing, the next step required a plan for how this information pool could be best accessed. To this end, Neurath attempted to create and systematize iconic forms of communication that could work on an intercultural basis. As the outcome, ISOTYPE resembled more a lingua franca than an ideal or universal language, but it also had helpful features beyond those of ordinary language. These

2 The best representation of the pictorial work is the publication Gesellschaft und Wirtschaft. Bildstatistisches Elementarwerk (Leipzig: Bibliographisches Institut), 1930. For an assessment see the chapter by Sybilla Nikolow in this volume. 
features derived from its use of pictures rather than numbers or words. Neurath conceived his picture language as a Cartesian ideal, 'an education in clear thought', which as an international system would serve the purpose of 'debabelization' (Ogden 1931) in business and science (Neurath 1936, 13).

\section{The Power of Pictograms}

The power of images in culture has been intensely discussed in recent years, and it has been stated that there is no such thing as an 'unmediated representation' (Mitchell 1986, 30). For any kind of 'debabelization' using images, there is no simple way back to images antecedent to the written tradition and print, though, in discussing electronic media, Marshall McLuhan believed that these media would enable our culture to 'return to the inclusive form of the icon' (McLuhan 1964, 12). By designing the ISOTYPE picture language and emphasizing the unifying aspect of pictures, Neurath, long before McLuhan, had envisioned an 'inclusive form' of visual communication that would be available to working class people who were unable or unwilling to accept the cultural offers of literacy. The iconic forms for which he aimed were means to an end with strong political implications. Bypassing certain conditions of what later was called the 'alphabet effect' in western culture (Logan 1986), Neurath believed that knowledge should be made accessible independently of an individual's educational background. Systematizing pictorial representation in a new pictorial language would help to provide generally accessible overviews and identify connections otherwise distorted by abstract verbal or numerical expressions. He imagined a new media culture in which every person would have access to knowledge through a pictorial experience. And as if supporting these ideas, two decades later media philosopher McLuhan stated (without making reference to Neurath, it should be noted):

Whereas the written vernaculars have always locked men up within their own cultural monad, the language of technological man, while drawing on all the cultures of the world, will necessarily prefer those media which are least national. The language of visual form is, therefore, one which lies to hand as an unused Esperanto at everybody's command. The language of vision has already been adopted in the pictograms of scientific formula and logistics. These ideograms transcend national barriers as easily as Chaplin or Disney and would seem to have no rivals as the cultural base for cosmic man (McLuhan 1953).

The new method of representation and iconic communication put forward by Neurath arose from his observation that general accessibility to knowledge was more easily attainable through immediate visual presentations than through more roundabout campaigns to achieve alphabetic literacy. He recognized that the power of pictograms, as a new means or technique of communication, had been developing for some time and provided a substantial basis for a new cultural order of things. As he remarked:

Modern man receives a large part of his knowledge and general education by way of pictorial impressions, illustrations, photographs, films. Daily newspapers bring more 
pictures from year to year. In addition, the advertising business operates with optical signals as well as representations. Exhibitions and museums are indeed offspring of this

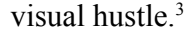

Neurath made frequent reference to the philosopher and educator Johann Amos Comenius, whose 'Orbis sensualium pictus' (1653) was a source and inspiration for the use of pictures in education. In fact Neurath planned to publish an atlas on the history of civilization as a new 'Orbis pictus' in cooperation with Paul Otlet and the Mundaneum (see Charles van den Heuvel's chapter in this volume).

Another source for his work was nineteenth-century picture statistics or statistical charts. ${ }^{4}$ The economist William Playfair, for example, developed picture statistical methods for showing the balance of trade in his 'Statistical Breviary,' published in London 1801. Another popular picture statistics was devised by Michael George Mulhall. His acclaimed 'Dictionary of Statistics' was published in 1893, but his approach of illustrating quantities by means of smaller or larger images found its critics. Among them was Willard C. Brinton, who published a new 'Graphic Methods for Presenting Facts' in 1914 and whose work may have directly influenced Neurath in adopting the idea of representing quantities through a serialization of images of the same size, instead of enlarging the size of the image.

The need to depict quantities underlay some of the specific characteristics of ISOTYPE. Neurath's idea was neither to illustrate a piece of text or a figure nor to give any illusion of unmediated representation, as might be the case if photography or film were used. He trusted only statistics to give an unbiased view of social and economic reality. By enabling such a view, pictorial statistics would eventually become, he believed, a revolutionary instrument for social sciences.

The Belgian mathematician Adolphe Quételet worked out the foundations of statistical methodology in the nineteenth century. For his anthropometrical research he developed a way of expressing the normal distribution of mean values of measurable variables. The Quetelet index is still in use today, although better known as the bodymass-index. His 1835 publication, 'Sur l'homme' [Treatise on Man, 1835], presented a 'social physics' in which these values were used to describe crime or suicide rates within the frame of statistical laws. Eventually, this led him to the concept of 'l'homme moyen,' or the average man. This average man is not a character. He has no personality, no individual features. He is simply a statistical phenomenon.

It was Neurath's graphic designer, Gerd Arntz, who was to develop the average visual figures for expressing statistical phenomena in ISOTYPE charts. These basically meaningless visuals were meant to be serialized and to be put in relation with each other. Eventually, the pictorial elements would be used according to specific rules and therefore would function as 'picture language' (Neurath 1936, 33). The expressions of such a picture language could be created in lines and represented in charts to form Mengenbilder ('amount-pictures' or 'number-fact pictures'), which according to Neurath would be especially valuable for educational purposes.

3 Quoted and translated from Neurath (1926).

4 For some aspects of the visual display of quantitative information and its history see Tufte (2001). 

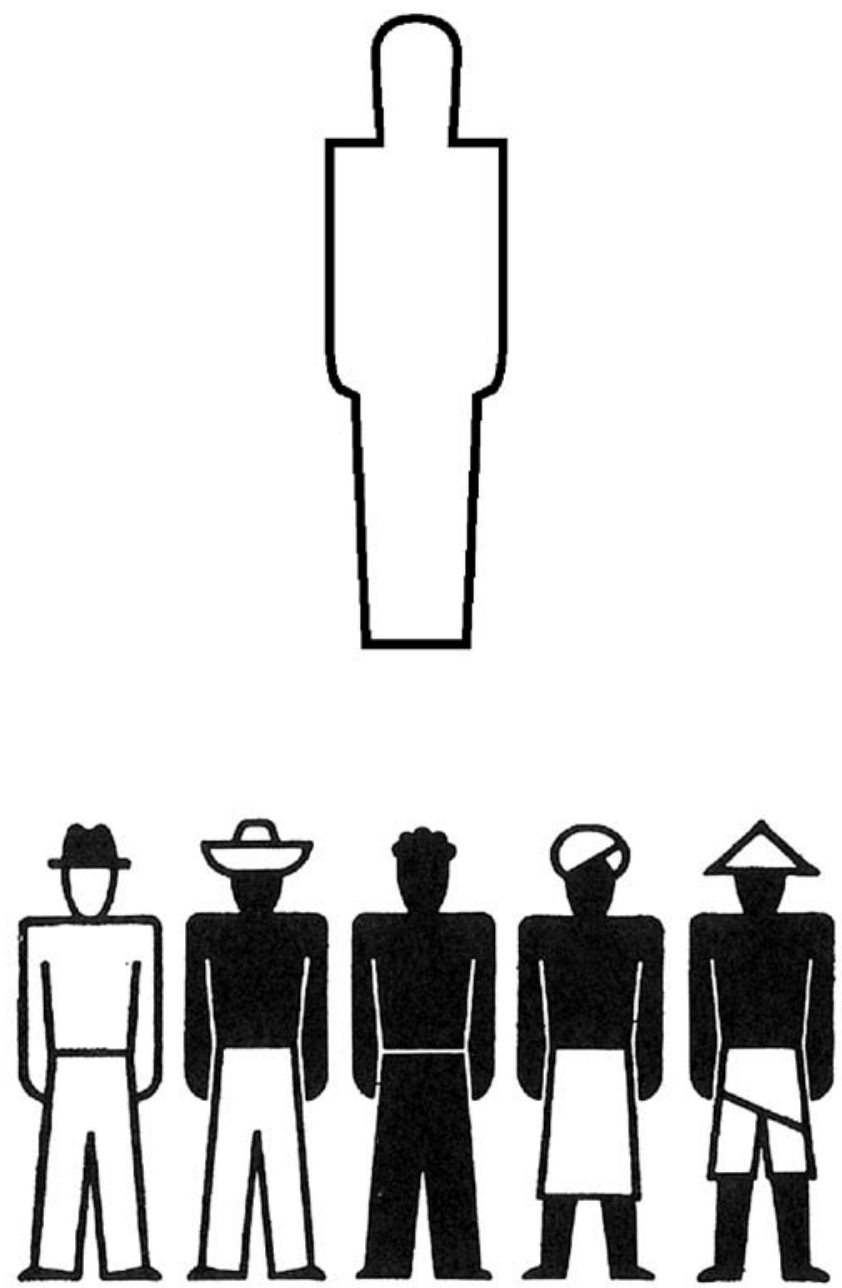

Figure 15.3 Outline of the average man, some specifications (section) (Neurath 1936, 47)

\section{Characteristics of ISOTYPE}

To create an ISOTYPE chart for statistical data, numbers had to be transformed into specific pictograms, which were then linocut and reproduced by print. Specific attributes could be added to a particular basic pictogram so that the figure of a workman, for example, could be distinguished by gender, profession, or some other characteristic, such as 'unemployed' or 'on strike' (Figures 15.3 and 15.4).

In the ISOTYPE picture language, the average man is turned into a figure for use in a statistical chart to represent a certain quantity, which usually was explained in the caption (Figure 15.5). 

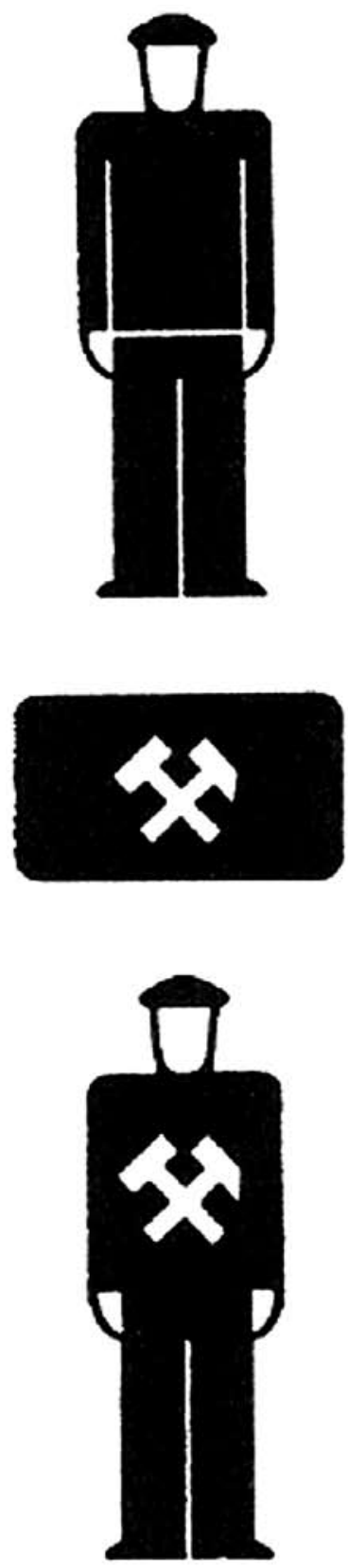

Figure 15.4 A 'worker' and the specification as coal 'worker' (Neurath 1936, 53)
The techniques for achieving an unambiguous ISOTYPE expression were developed by Neurath and Arntz according to a set of simple rules known as the 'Vienna method' before 1934 (the year of the team's emigration from Vienna to The Hague), and as the 'International Picture Language' after 1935. ${ }^{5}$ For all of the text on the charts, as well as in his international publications, Neurath used 'Basic English,' developed and publicized in the 1930s by Charles Kay Ogden and his British Orthological Institute. ${ }^{6}$

The ISOTYPE method, to put it simply, was to create signs that would be as close as possible to what they stood for (that is, depicting an object with the highest possible iconicity), technically reproducible and able to be used consistently: the same signs for the same things, and more of the same signs instead of bigger signs for larger numbers of things. The rules for the new pictorial script were simple yet strict:

A picture produced after the rules of the Viennese Method shows the most important details of the object at the first glance; apparent differences must strike the eye immediately. At the second glance, it should be possible to distinguish the more important details, and at the third glance, whatever other details are to be seen. If a picture gives further information at a fourth or at fifth glance, it should be rejected as pedagogically unsuitable according to the Viennese School. ${ }^{7}$

The following rules for the forms and colors of components of the picture language can be extracted from Neurath's methodological observations:

- Serialization: concentrate on relations instead of representations; symbolize quantities through serialization of the same signs, not with bigger ones. A sign is representative of a certain quantity

5 Marie Reidemeister, Neurath's colleague and later his third wife, actually coined the acronym ISOTYPE while preparing two Institute publications for Charles K. Ogden in 1935.

$6 \quad$ BASIC $=$ British American Scientific International Commercial. 'Basic English is a careful and systematic selection of 850 English words which will cover those needs of everyday life for whch a vocabulary of 20.000 words is frequently employed' (Ogden 1930).

7 Quoted and translated from Neurath (1933). 


\section{Automobiles of the Earth}

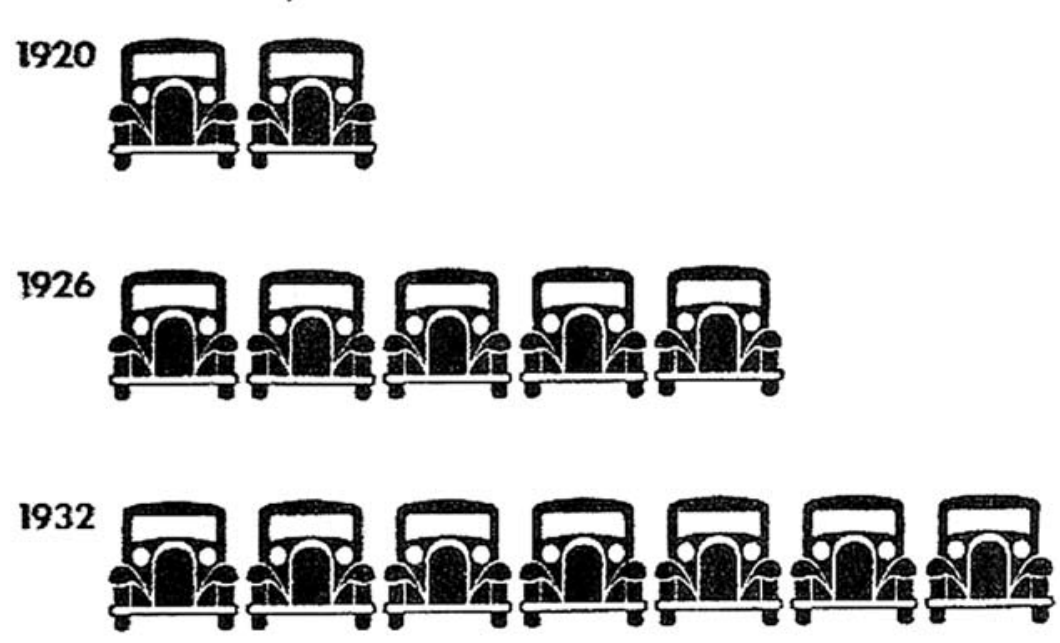

Every sign 5 millian owtamobile:

Figure 15.5 'Every sign 5 million automobiles' (Neurath 1936, 47)

of things; a greater number of signs is representative of a larger quantity of things.

- Iconicity: create a limited number of signs for international use, and stick to one overall design. Signs should be clear in themselves, without the help of words as far as possible.

- Clarity: the man of science has to make clear-cut statements on which other clear-cut statements in different branches of science may be based;

- Consistency: in the use of signs, no perspective is to be used; the signs are to be put in lines like letters, which could be composed into charts. Giving a sign its fixed form for international use, possibly for a great number of years, was challenging work.

- Color: colors emphasize different divisions in a common group. They make clear that a sign of the same form has a different meaning. The rules for forms are more strict than those for colors.

\section{Educational Impact of ISOTYPE}

'Internationalization' became a key term in the decades around 1900. Railroads, steamboats and the telegraph had changed the nature of international traffic in goods and ideas and had created an international communications infrastructure. Communication was recognized as having a central role in social organization, although terms like communication, information and media were not used at the time (for an exception see Cooley 1909). Concepts of standardization and 
unification were widely used, reflecting an interest in facilitating the emerging global scope of commercial and other interests (from world traffic and world language to the world brain). As author of the International Picture Language, Neurath assumed the title of 'Director of the International Foundation for Visual Education'.

Developing an effective sign language involved a recognition of the need for a new kind of media literacy, one which was not limited to a particular form of access to knowledge such as written language. For Neurath institutions like Otlet's 'Mundaneum Institute' could provide the backup for the new approach that he was developing, which he presented as leading to the creation of an international encyclopedia that would continue the ideas of eighteenth-century enlightenment.

Yet Neurath was quite aware of the limitations of the International Picture Language. Designed as a helping language, the ISOTYPE project, working in association with socialist politics and economy, could only provide 'the first conditions necessary' for an 'education of public opinion'.

Ideas of what is important are not the same at all times or in all countries, and this fact makes the designs different. Sometimes the head of a man seems important, sometimes not; sometimes even the hands and the fingers seem important. Certainly the ISOTYPE signs are dependent on their times like all these old sign-languages. Later times will see what their special qualities are and what the conditions were which made them (Neurath 1936, 106).

A historical path exists for Neurath from ancient hieroglyphs to the use of pictures in encyclopedias and thence to modern picture education (Neurath 1946). It is interesting to speculate about how his quest for an increase in iconicity worked for the project of 'debabelization'. How does the design of a picture language like Neurath's, depending as it does on the continuous interpretation of the signs which are used, deal with the problems of semantics?

Memories of his childhood, Neurath claimed, led him to cherish Egyptian hieroglyphs, which he assumed stood as direct representatives of things and ideas, as opposed to words or sounds. But when Francois Champollion decoded hieroglyphic writing from the Rosetta Stone in 1822, it became clear that these signs did not simply depict things but were often phonetic characters and also highly symbolic. Neurath seems not to have been aware of this, since he imagined hieroglyphs to be iconic shortcuts for meanings. Since the evolution of language is not a simple move from concrete pictures to abstract words, there is no simple way back to such iconicity.

Modern interface culture uses iconic signs in abundance. Computer screens and the World Wide Web present an orgy of pictorial signs that may be interpreted as a kind of a helping language as envisioned by Neurath. But these signs represent not objects but algorithmic processes. As for pictograms used in public communication, semiotics allows us to distinguish between pictographic and ideographic signs. The table shown in Figure 15.6 is designed as a thought-game that invites the English speaker to imagine designing a written form for English outside the Latin alphabet - the obstacles are quite obvious. 


\begin{tabular}{|c|c|}
\hline pictograph & ideograph \\
\hline 象形文字 & 表意文字 \\
\hline $\begin{array}{l}\text { man and woman } \\
\text { 女と男 }\end{array}$ & $\begin{array}{l}\text { toilets } \\
\text { rRL }\end{array}$ \\
\hline knife and fork & restaurant \\
\hline フッークとナイフ & レストラン \\
\hline a man dreams of a question & hotel information \\
\hline 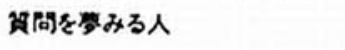 & ホテル インフォメーショ \\
\hline a car dreams of a key & car rental \\
\hline 虾と营みる畒 & レンタカー \\
\hline
\end{tabular}

Figure 15.6 Modern Hieroglyphs (from Lupton and Miller 1996, 46)

While pictographs are figurative signs that may be interpreted for their literal meanings, reading them as a picture language may lead to confusion. In other words, it is misleading to think of pictographic writing as existing outside a certain culture and context. There is no such thing as a 'thing', and although there are certain signs which relate to certain objects in the table shown in the figure (like 'car' or 'key'), the implications for meaning become extremely complex when we combine them. 'A car dreams of a key' might be called poetic, but it is hard to imagine a sign being interpreted like this in everyday communications. At the airport, we are more likely to interpret this sign as 'car rental', thus treating it as an ideograph, and not as a pictograph.

\section{Conclusion: Toward a New Visual Culture}

Neurath seems to have been aware of some of the arbitrariness and the historical context implicit in sign writings. Pictographic writings, he observed, like Chinese writing 'have been formed by reasoning, and by hundreds of years of use' (Neurath $1936,105)$. What is important in Neurath's visual education project is not the notion of truth in the modes of representation he adopted, be it in pictures or words, but the pragmatics of the use of signs.

He presented the construction of signs and the rules for using them on the same level of importance. Together they offer a kind of information aesthetics, which allows quick navigation based on intercultural common sense - they constitute a streamlining for easy judgment. To 'represent things', then, is not possible without a certain bias toward what nowadays must be called 'faitiche' - or factish, a combination of fact and fetish (Latour 1999) - indicating the crucial element of fabrication inherent in the pictures. This is an obvious problem in contemporary media production and with the increased role of the image in science, that is, the increasing dependence on 


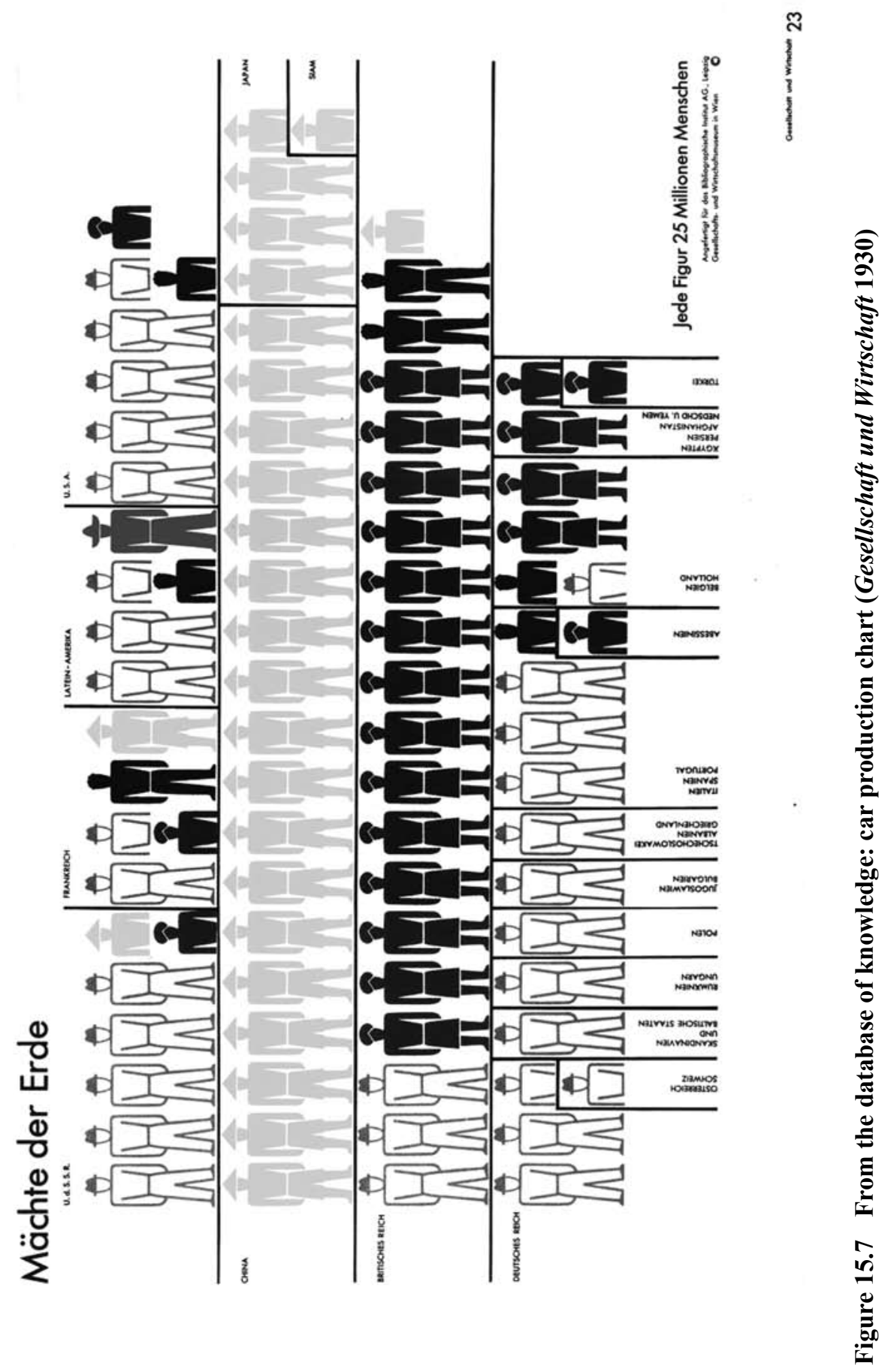


illustrations arising from the widespread use of computer graphics. The problem is especially evident when images are used to depict mechanisms beyond human perception like cell mechanisms, the DNA code, prehistoric realities or the devices of nanotechnology. The extended possibilities of digital design can help to visualize the unseen but they can also threaten scientific plausibility (Ottino 2003).

Neurath and his team not only established standards for presenting statistical data but also influenced generations of graphic and interface designers. ${ }^{8}$ Information graphics became a genuine aspect of any kind of news publication whose conventions, in print as well as on computer screens, can be traced back to some extent to the innovations inherent to the ISOTYPE project. This is why Neurath's International Picture Language is a genuine product of the laboratory of modernity, for 'Modern Man in the Making' (Neurath 1939). The hidden effects of this pioneering work can be found in most of today's visual culture. Its characteristic is not a return to pictures before writing; instead it is a fast-forward toward new visuals, toward a 'culture of techno-images' (Flusser 2002, 67) full of pictures which do not represent objects but texts, ideologies, programs or algorithms. From letters to numbers to digital code, modernity has seen an increasingly abstract mode of encoding, which puts an emphasis not so much on the mode of interpretation but on communications technology as the condition for mediation.

Neurath did not experience the final results of the shift in perspective in relation to the new technologies, the technical transformations of the computer age. But 1945, the year of Neurath's death, saw the electronic information revolution on its way. ENIAC, the first full scale electronic computer, was built as a general-purpose machine, thus heralding the information age in which computers would not only transform the storage and the distribution of information, but transform communication itself - the ways in which we perceive information and how we interact with the data universe. Way ahead of this transformation, which was one from script to digits, Neurath was surprisingly attentive to information processes in culture. His vision reached beyond a revision of graphic communication. He regarded cultural communication (and visual education) as a form of data processing following what one might describe as a new cultural algorithm. ${ }^{9}$ For Neurath, the International Picture Language in the end would serve not only as the lingua franca in a globalized economy, but as an iconic interface to the global database of knowledge.

\section{References}

Carnap, R., Hahn, H. and Neurath, O. (1929), Wissenschaftliche Weltauffassung - der Wiener Kreis [The scientific conception of the world: the Vienna Circle], in Sarkar, S. (ed.) (1996), The Emergence of Logical Empiricism: From 1900 to the Vienna Circle (New York: Garland Publishing).

8 In Europe, to name but the most prominent, Otl Eicher and Adrian Frutiger; in the United States, Rudolf Modley, who worked for Neurath in Vienna ca. 1928, and the Dymaxion World Map project by Buckminster Fuller. Here the tradition of information graphics (alas, without any reference to Neurath!) is prominent with graphic artist Edward R. Tufte.

9 For this concept of database as a cultural form, see Manovich (2001). 
Cooley, C.H. (1909), Social Organization: A Study of the Larger Mind (New York: Charles Scribner's Sons).

Eco, Umberto (1995), The Search for the Perfect Language (Oxford: Blackwell Publishers).

Flusser, V. (2002), Writings (Minneapolis: The University of Minnesota Press).

Frege, G. (1879), Begriffsschrift, eine der arithmetischen nachgebildete Formelsprache des reinen Denkens [Concept Writing: a formalized language of pure thought modelled on the language of arithmetic] (Halle a/S: L. Nebert).

Gesellschaft und Wirtschaft (1930). Gesellschaft und Wirtschaft. Bildstatistisches Elementarwerk (Leipzig: Bibliographisches Institut).

Hartmann, F. and Bauer, E.K. (2006), Bildersprache. Otto Neurath, Visualisierungen (Vienna: WUV).

Haller, R. and Kinross, R. (eds) (1991), Otto Neurath. Gesammelte bildpädagogische Schriften (Vienna: Hölder-Pichler-Temspky).

Latour, B. (1999), Pandora's Hope: An Essay on the Reality of Science Studies (Cambridge, MA: Harvard University Press).

Logan, R.K. (1986), The Alphabet Effect: The Impact of the Phonetic Alphabet on the Development of Western Civilisation (New York: Morrow).

Lupton, E. and Miller, A. (1996), Design, Writing, Research (New York: Princeton Architectural Research).

Manovich, Lev (2001), The Language of New Media (Cambridge, MA: The MIT Press).

McLuhan, M. (1953), 'Culture Without Literacy', Explorations 1, 117-27.

McLuhan, M. (1964), Understanding Media: The Extensions of Man (New York: McGraw-Hill).

Mitchell, W.J.T. (1986), Iconology: Image, Text, Ideology (Chicago: The University of Chicago Press).

Modley, R. (1937), How to Use Pictorial Statistics (New York: Harper).

Modley, R., Myers, W.R. and Comer, D.G. (1976), Handbook of Pictorial Symbols (New York: Dover Publications).

Neurath, O. (1926), 'Statistische Hieroglyphen', Österreichische Gemeinde-Zeitung 3:10, 328. Reprinted in Haller and Kinross (1991), 40.

Neurath, O. (1933), 'Museums of the Future', Survey Graphics 22, 458-63. Reprinted in Haller and Kinross (1991).

Neurath, O. (1936), International Picture Language (London: Kegan Paul). Facsimile reprint: Reading, UK: Department of Typography \& Graphic Communication, University of Reading, 1980.

Neurath, O. (1937), 'Inventory of the Standard of Living', in Horkheimer, M. (ed.), Zeitschrift für Sozialforschung VI, 140-51.

Neurath, O. (1939), Modern Man in the Making (New York: A. Knopf).

Neurath, O. (1946), From Hieroglyphics to Isotype (London: Future Books).

Neurath, O., Carnap, R. and Morris, C.F.W. (eds) (1938), Foundations of the Unity of Science: Toward an International Encyclopedia of Unified Science (Chicago: The University of Chicago Press).

Ogden, C.K. (1930), Basic English: A General Introduction with Rules and Grammar (London: Treber). 
Ogden, C.K. (1931), Debabelization (London: Kegan Paul).

Ottino, J.M. (2003), 'Is a Picture Worth 1000 Words?' Nature 421 (January), 474-6.

Quetelet, A. (1835), Sur l'homme et le développement de ses facultés, ou, Essai de physique social (Paris: Bachelier).

Tufte, E.R. (2001), The Visual Display of Quantitative Information (Cheshire, CT: Graphics Press). 
